NBER WORKING PAPER SERIES

\title{
AN INVESTIGATION OF THE EFFECTS OF ALCOHOL POLICIES ON YOUTH STDs
}

\author{
Michael Grossman \\ Robert Kaestner \\ Sara Markowitz \\ Working Paper 10949 \\ http://www.nber.org/papers/w10949 \\ NATIONAL BUREAU OF ECONOMIC RESEARCH \\ 1050 Massachusetts Avenue \\ Cambridge, MA 02138 \\ December 2004
}

Funding for this research was provided by grant number DA12692-03 from the National Institute on Drug Abuse to the National Bureau of Economic Research. The authors would like to thank Jeff DeSimone, Hope Corman, Jody Sindelar, Will Manning and seminar participants at iHEA, University of South Florida and the 24th Arne Ryde Symposium on the Economics of Substance Use for helpful comments. This paper has not undergone the review accorded official NBER publications; in particular, it has not been approved by the Board of Directors. Any opinions expressed are those of the authors and not those of the authors and not those of NIDA or NBER.The views expressed herein are those of the author(s) and do not necessarily reflect the views of the National Bureau of Economic Research.

(C) 2004 by Michael Grossman, Robert Kaestner, and Sara Markowitz. All rights reserved. Short sections of text, not to exceed two paragraphs, may be quoted without explicit permission provided that full credit, including (C) notice, is given to the source. 
An Investigation of the Effects of Alcohol Policies on Youth STDs

Michael Grossman, Robert Kaestner, and Sara Markowitz

NBER Working Paper No. 10949

December 2004

JEL No. I1

\begin{abstract}
$\underline{\text { ABSTRACT }}$
The purpose of this paper is to examine the role of alcohol policies in reducing the incidence of sexually transmitted diseases among youth. Previous research has shown that risky sexual practices (e.g., unprotected sex and multiple partners) that increase the risk of contracting a STD are highly correlated with alcohol use. If alcohol is a cause of risky sexual behavior, then policies that reduce the consumption of alcohol may also reduce the incidence of STDs. In this paper, we examine the relationship between alcohol policies (e.g., beer taxes and statutes pertaining to alcohol sales and drunk driving) and rates of gonorrhea and AIDS among teenagers and young adults. Results indicate that higher beer taxes are associated with lower rates of gonorrhea for males and are suggestive of lower AIDS rates. Strict drunk driving policies in the form of zero tolerance laws may also lower the gonorrhea rate among males under the legal drinking age.

Michael Grossman

NBER

365 Fifth Avenue, 5th Floor

New York, NY 10016-4309

and City University of New York

mgrossman@gc.cuny.edu

Robert Kaestner

Institute of Government and Public Affairs

University of Illinois at Chicago

815 West Van Buren Street, Suite 525

Chicago, IL 60607

and NBER

kaestner@uic.edu

Sara Markowitz

NBER

365 Fifth Avenue, 5th Floor

New York, NY 10016

and Rutgers University, Newark

smarkow@rutgers.edu
\end{abstract}




\section{Introduction}

When compared to older adults, teenagers and young adults are particularly at risk for contracting a sexually transmitted disease (STD). Incidence rates of chlamydia and gonorrhea-the two most common reportable STDs-- are highest among American teenagers and young adults. In 2002, chlamydia incidence was 297 per 100,000 population for persons of all ages, 1,483 for teenagers, and 1,610 for young adults (CDC 2003). Similar age disparities are found for gonorrhea, with incidence rates per 100,000 population of 125 , 476, and 593, respectively. Moreover, approximately half of all new human immunodeficiency virus (HIV) infections in the United States occur among people under age 25 (CDC 2002). These statistics make clear that teenagers' sexual behaviors are adversely affecting their health and development.

The high rates of STDs and risky sexual practices of teens have motivated researchers to look for causes of these behaviors. Numerous studies have shown a positive association between substance use and risky sexual practices. ${ }^{1}$ For example, Graves and Leigh (1995) show that young adults who drink heavily are more likely to be sexually active and to have multiple partners, and those who are heavy drinkers are also less likely to use condoms. Similar evidence also comes from Strunin and Hingson (1992) and Fergusson and Lynskey (1996) who show that alcohol use by teenagers is associated with unprotected intercourse. Regrettably, all of these sexual behaviors have been shown to increase the risk of contracting STDs (Laumann et al. 1994).

The policy implications of this research are important. If alcohol consumption causes youth to engage in unsafe sexual practices, then reductions in alcohol consumption will also

\footnotetext{
${ }^{1}$ For a review of this literature see Leigh and Stall (1993) and Donovan and McEwan (1995).
} 
reduce the negative outcomes associated with unsafe sex. On the other hand, if alcohol consumption is simply correlated with risky sexual behavior, then (exogenous) reductions in consumption would have no effect on teens' risky sexual behaviors. Therefore, policies that are known to affect alcohol consumption can be used to identify indirectly the effect of such consumption on risky sexual behaviors and STDs. In fact, many studies have shown that alcohol consumption is responsive to changes in alcohol prices (see Leung and Phelps 1993 and Cook and Moore 2000 for reviews). Studies focusing specifically on youth consumption also show a responsiveness to policies pertaining to availability, such as the minimum legal drinking age (Grossman et al. 1994; Moore and Cook 1995; Grossman et al. 1998) and zero tolerance laws (Carpenter 2004).

In this paper, we examine the relationship between STD rates and prices and policies pertaining to the consumption of alcohol. This research strategy makes use of the known relationship between alcohol control policies and alcohol consumption to indirectly study the effect of alcohol consumption on risky sexual behavior and STDs. More importantly, we provide evidence on the effect of policy tools that legislators can use to affect teen and young adult behavior.

\section{Previous Research}

While the bulk of the existing research on substance use and risky sex describes a positive correlation between these behaviors, researchers have just begun to examine the causal nature of the substance use-risky sex link. To establish causality it is essential to address the non-random nature of substance use and risky sexual behavior. Economists have taken the lead in this area. Recent studies by economists have attempted to go beyond simply measuring the 
correlation by using methods that account for non-random selection. The results of these studies are mixed. Alcohol use has been reported to lower contraception use among young women (Kaestner and Joyce 2001) and teens of both genders (Sen 2002; Grossman and Markowitz, forthcoming), and to increase the probability of having sex (Sen 2002). By contrast, heavy alcohol use and drunkenness appear to have no causal impacts on the probabilities of having sex among teens (Rees et al. 2001; Sen 2002; Grossman and Markowitz forthcoming; Grossman et al. forthcoming) or using protection among young females (Rees et al. 2001; Sen 2002). However, Rees et al. (2001) find that drunkenness may lead to a lower probability of contraception use among males. The mixed nature of these findings is not easily reconciled by theoretical considerations and a recent study by Rashad and Kaestner (2004) calls into question the validity of the methods used to obtain estimates reported by Rees et al. (2001) and Sen (2002). Therefore, the question of the causal relationship between teen alcohol use and risky sex remains largely unanswered.

Very little research has examined the causal relationship between alcohol or drug use on outcomes of risky sexual practices. Kaestner and Joyce (2001) examine the effects of substance use on the probability of unintended pregnancy. They find that among whites, alcohol use increases the likelihood of unintended pregnancy while drug use has no statistically significant effects. They also find that substance use is statistically unrelated to unintended pregnancy for blacks and Hispanics. Dee (2001) reaches an alternate conclusion in his study on changes in the minimum legal drinking age and childbearing among teens and young adults. Using a panel of state level data across time, he finds evidence that reductions in alcohol consumption encouraged by higher drinking ages reduced the childbearing rates of blacks, while having an uncertain effect on childbearing rates of whites. The discrepancy in the conclusions between Dee's study 
and that of Kaestner and Joyce (2001) may arise because of differences in the outcomes studied (childbearing rates versus unintended pregnancies), time period under consideration (1977-1992 versus 1984 and 1988), and unit of observation (state versus individual). It is clear however, that much is still unknown about the relationship between alcohol consumption and teenage sexual behaviors and outcomes.

Three other studies have analyzed the relationship between alcohol and risky sexual behaviors indirectly by examining the relationships between alcohol control policies and STDs, another outcomes of risky sexual behaviors. This approach relates the exogenous determinants of alcohol consumption (i.e. public policies such as the excise tax on beer) directly to STD rates. Causal relationships are inferred since the only way that these policies should affect STD rates directly is through reduced consumption and risky sexual practices.

Chesson et al. (2000) show that gonorrhea and syphilis rates fall as the state beer or liquor tax rises. To obtain these estimates, Chesson et al. (2000) use a time series of statelevel data for the years 1981 through 1995 and controls for state and year effects. The results stated above apply to persons of all ages, young adults, and male teenagers. In addition, Chesson et al. (2000) report that increases in the minimum legal drinking age lower the gonorrhea rate for youths ages 15-19.

Scribner et al. (1998) report a negative relationship between gonorrhea rates and alcohol outlet density among urban residential census tracts in New Orleans in 1995. However, it is unknown whether this relationship is causal, or whether the effects reflect a correlation with other neighborhood and individual characteristics. For example, people with a taste for multiple risky behaviors may be clustered in high outlet density neighborhoods. 
Lastly, Carpenter (forthcoming) examines the effect of zero tolerance laws for under-age drunk driving in reducing gonorrhea rates over time. Zero tolerance laws are associated with reduced alcohol consumption among teens (Carpenter 2004), and therefore might also affect other outcomes associated with alcohol consumption. Indeed, Carpenter finds that the adoption of zero tolerance laws are associated with a reduction in gonorrhea rates for white males ages $15-19$, although the results are mixed for white females and are statistically insignificant for black males and females.

This paper adds to the existing literature by examining the impact of alcohol prices on gonorrhea and AIDS rates for teenagers and young adults. In its basic structure, this paper is similar to that of Chesson et al. (2000), whose primary focus is the impact of beer and liquor taxes on the determinants of gonorrhea and syphilis rates among people of all ages. Our paper differs, however, in a number of respects. First, our sample consists only of youth, and includes an analysis of AIDS, which is more prevalent than syphilis. ${ }^{2}$ Second, our data on gonorrhea rates extends over a longer and more recent time period. Third, along with the price of alcohol, we include a number of other alcohol regulatory variables. The inclusion of drunk driving laws and a measure of alcohol availability are other novel aspects of this paper. Lastly, our estimation strategy differs somewhat from that of Chesson et al. Details are described in the next section.

\section{Methods}

The empirical specification is based on the notion that risky sexual behaviors may lead to

\footnotetext{
${ }^{2}$ Chlamydia is also a very common STD, however, data on state level rates have only been available for most states since 1996. In addition, screening and treatment programs that are primarily directed towards women lead to
} 
the contraction of a STD. Alcohol consumption may contribute to the contraction of the STD because of its effect on risky sexual behavior. Therefore, the exogenous determinants of alcohol use are hypothesized to reduce STD rates through decreased consumption. The regression model is specified as follows:

$$
\operatorname{Ln}\left(\operatorname{STD}_{\mathrm{jt}}\right)=\alpha_{0}+\alpha_{1} \mathrm{P}_{\mathrm{jt}}+\alpha_{2} \mathrm{X}_{\mathrm{jt}}+\alpha_{3} \gamma_{\mathrm{j}}+\alpha_{4} \tau_{\mathrm{t}}+\varepsilon_{\mathrm{jt}}
$$

Equation (1) specifies that the natural logarithm of the STD rate (STD) for a gender and age group in an area $(\mathrm{j})$ at a point in time $(\mathrm{t})$ is a function of area alcohol regulatory variables $\left(\mathrm{P}_{\mathrm{jt}}\right)$, other characteristics of the population of the area $\left(X_{j t}\right)$, area effects $\left(\gamma_{j}\right)$, year effects $\left(\tau_{t}\right)$, and an error term. The vector of coefficients on $\mathrm{P}_{\mathrm{jt}}$ will show whether alcohol policies influence STD rates. Given the strong evidence mentioned above linking alcohol policies to consumption, we assume that any estimated effects of the policies work through a reduction in consumption. After accounting for area characteristics and time trends, there is little reason to believe that substance use policies may affect STD rates in any other way except through changes in consumption.

The estimation of AIDS rates entails an added difficulty in that the cases are reported to public health officials only after the individual has developed symptoms of AIDS. This may occur many years after the initial transmission of the HIV virus. ${ }^{3}$ Given this lag, the alcohol regulatory variables should be matched to the date of initial viral transmission rather than the date of diagnosis. Unfortunately, it is not possible to match each case with the infection date. We use instead the average length of time between transmission of the HIV virus and symptomatic AIDS infection, which is eight years (Bartlette and Gallant 2003). The equation for AIDS therefore includes an eight year lag of all the independent variables:

reporting biases (CDC 2000b). Given the short time period and biases in the reported data, chlamydia rates are not analyzed in this paper.

${ }^{3}$ By contrast, gonorrhea has an incubation period of less than a week. 


$$
\operatorname{Ln}\left(\mathrm{AIDS}_{\mathrm{jt}}\right)=\alpha_{0}+\alpha_{1} \mathrm{P}_{\mathrm{jt}-8}+\alpha_{2} \mathrm{X}_{\mathrm{jt}-8}+\alpha_{3} \gamma_{\mathrm{j}}+\alpha_{4} \tau_{\mathrm{t}-8}+\varepsilon_{\mathrm{jt}}
$$

Two problems may arise in estimating equations 1 and 2. First, the residual may be serially correlated if there exists unobserved state-specific time-varying factors. Persistent discrepancies in state reporting practices or screening programs might cause the error terms to be correlated across time within a state. Bertrand et al. (2004) show that this is an especially serious problem when independent variables are positively correlated over time because they change infrequently. For example, dichotomous policy variables may change only once in the sample period. Thus, we adopt the Bertrand et al. (2004) correction for serial correlation by computing robust standard errors that allow for clustering by area (state for gonorrhea, MSAs for AIDS).

The second problem arises if the incidence rate of communicable diseases depends on the past incidence or prevalence of the disease. This suggests that the lagged STD rate should be included in the equations. ${ }^{4}$ Nickell (1981), Baltagi (2001), and others show that the coefficient of the lagged dependent variable is inconsistent in a fixed-effects model applied to a panel even if the disturbance term is serially uncorrelated. The reason is that in the standard fixed effects estimation procedure the lagged dependent variable is correlated with the error term which includes the mean error. This inconsistency will translate to the coefficients of other regressors that are correlated with the lagged dependent variable.

To address this problem, we adopt alternative methods to account for the lagged dependent variable. The first is a reduced form equation which replaces the lagged STD rate with some of its determinants, and the second directly includes the lagged STD rate. The reduced form OLS equations include lagged beer taxes and percent dry as additional regressors. For gonorrhea only one lag is included (year t-1). Further lags proved to be statistically 
insignificant and are omitted because they do not contribute to the models. For AIDS, we include two lags of the beer tax (years t-9 and t-10) since these prove to be jointly statistically significant in the models. Further lags of the beer tax are insignificant, as is the second lag of the percent dry, which is omitted.

Models that include a lagged dependent variable apply two methods: OLS and a firstdifference two-stage least squares (FD2SLS) estimator (Baltagi 2001). The OLS estimates are inconsistent but the FD2SLS may encounter problems due to random measurement error in the regressors. Inconsistencies due to this phenomenon are exacerbated by taking first differences, and may be particularly apparent when AIDS is considered as there is uncertainty as to the timing of the initial infection and the corresponding alcohol regulatory variables. The FD2SLS estimator is constructed by taking first differences of all variables and thereby eliminating area fixed effects. The lagged first-differenced STD rate $\left(\mathrm{STD}_{\mathrm{jt}-1}-\mathrm{STD}_{\mathrm{jt}-2}\right)$ is correlated with the first-differenced residual $\left(\varepsilon_{\mathrm{jt}}-\varepsilon_{\mathrm{jt}-1}\right)$ since $\mathrm{STD}_{\mathrm{jt}-1}$ is correlated with $\varepsilon_{\mathrm{jt}-1}$. Hence, the second lag of $\mathrm{STD}\left(\mathrm{STD}_{\mathrm{jt}-2}\right)$ is employed as an instrument for the lagged first difference $\left(\mathrm{STD}_{\mathrm{jt}-1}-\mathrm{STD}_{\mathrm{jt}-2}\right)$. Baltagi (2001) indicates that the second lag is highly correlated with the lagged difference in most applications, yet it is uncorrelated with the error term $\left(\varepsilon_{\mathrm{jt}}-\varepsilon_{\mathrm{jt}-1}\right)$ since future shocks have no impacts on lagged values of the dependent variable. ${ }^{5}$

When considering sexually transmitted diseases, it is questionable as to what is the appropriate lagged STD rate. If a disease is contracted through heterosexual sex then the lagged STD rate for the opposite sex may be appropriate. The opposite would hold when homosexual

\footnotetext{
${ }^{4}$ The omission of the lagged STD rate can also lead to serial correlation in the error term.
} 
sex is a mechanism of transmission (particularly when AIDS among males is considered).

Additionally, a one year time lag may be also too long a period to correctly identify which gender's lagged STD rate is appropriate. Therefore, two models of lagged STD rates are considered. One contains the lagged dependent variable, which is gender specific (columns 3 and 5 in the tables), and the other includes the lagged total rate for both genders (columns 4 and 6). Since the lagged total rate includes the lagged dependent variable, both models are still estimated by FD2SLS.

Our empirical approach differs in part from the one taken by Chesson et al. (2000) because they include the lagged dependent variable as an exogenous regressor. We treat it as endogenous. As shown in the results section below, the treatment of the lagged dependent variable can significantly influence the results.

\section{Data}

Gonorrhea and AIDS are currently on the list of nationally notifiable diseases. A notifiable disease is one for which "regular, frequent, and timely information regarding individual cases is considered necessary for the prevention and control of the disease." (CDC 2000a). Public health officials at state health departments and officials at the CDC determine which diseases are nationally notifiable. Each state, however, has the authority to determine which diseases are reportable, and reporting is mandated only at the state level. Reporting to the CDC is voluntary, although all states typically participate.

\footnotetext{
${ }^{5}$ The coefficients on the second lags of the dependent variables are negative and statistically significant in the first stages of all models presented in the tables below. However, the magnitudes of these coefficients are much smaller for gonorrhea than AIDS. For example, the coefficient on the second lag of the male gonorrhea rate for ages 15-19 is -0.03 , with a standard error of 0.01 . In the AIDS regressions for males ages $20-29$, the coefficient is -0.33 with a standard error of 0.015 .
} 
The data used in this study was collected from state health departments and was provided to the CDC through the National Electronic Telecommunications System for Surveillance (NETSS). Reports for gonorrhea include the date of diagnosis, state of residence at diagnosis, age at diagnosis and gender. AIDS reports include date of diagnosis, age, gender and residence for people living in Metropolitan Statistical Areas (MSAs) with populations of 500,000 or more.

The annual number of reported cases of gonorrhea are available from the CDC beginning in 1981. Incident rates from 1981 to 2001 are calculated by gender for teens ages 15-19 and young adults ages 20-24. To create the rates, the number of reported cases in each state for each gender-age group is divided by the corresponding population of persons in that age category.

AIDS data for 103 large MSAs are available annually beginning in 1982 and are currently available through 2001. The data collected are for diagnosed cases of AIDS, not cases of HIV. The case definitions were modified in 1985, 1987, and 1993 to incorporate a broader range of indicator diseases and to include results of HIV tests. The data used in the paper contain all cases meeting the 1993 surveillance definition, the broadest definition (see CDC 1992 for details on the definition). Incident rates are created by gender for people diagnosed with AIDS at ages 20-29 and 30-34. Using the average eight year time period between initial viral transmission and the development of symptomatic AIDS, these individuals most likely contracted the disease between the ages of 12-21 and 22-26, respectively, thus providing a sample of teenagers and young adults. The population of the relevant age group in the MSA is used as the denominator in calculating the rate.

Since the FD2SLS models use the second lag of the dependent variable as an instrument, the first year of observation in these regressions is 1983 for gonorrhea and 1984 for AIDS. In order to keep the sample consistent and to allow for comparisons across the models, we exclude 
the first two years of data from all OLS models. The final sample size is 950 for gonorrhea and 1854 for AIDS. ${ }^{6}$ Excluding these beginning years makes little difference to the OLS results. Several variables are used to measure state-level alcohol regulations. First, the real (1982-1984=1) state and federal excise tax on a gallon of beer measures the price of alcohol. Beer taxes come from the Beer Institute's Brewers Almanac. The tax on beer is chosen because beer is the most popular alcoholic beverage among youths. Second, the percentage of each state's population living in counties dry for beer in each of the years is included. These data come from the Beer Institute's Brewers Almanac (various years). With larger percentages of populations living in dry counties, travel time to obtain alcohol increases, adding to the full price of alcohol. If alcohol consumption contributes to risky sexual practices, then it is expected that policies which make obtaining alcohol more costly will reduce STDs.

The other measures of alcohol regulation are indicators for the presence of blood alcohol concentration (BAC) laws. These laws make it illegal per se to drive with a blood alcohol concentration greater than a certain level. In 1981, 14 states had a BAC law of 0.10 or higher. In 1983, Oregon and Utah were the first states to pass a BAC law of 0.08. By 2000, almost all states passed BAC laws, with 20 states having 0.08 as the legal limit. Beginning in the mid 1980s, states also began enacting "zero tolerance" laws for underage drinking and driving. These laws typically set the BAC for underage drinkers at 0.02 or less. Federal legislation passed in 1995 encouraged all states to pass zero tolerance laws by allowing for the withholding of federal highway funds. By 1998, all 50 states plus the District of Columbia had a zero tolerance law in effect.

Three indicators for BAC laws are included: a dichotomous indicator for a BAC law of

\footnotetext{
${ }^{6}$ Georgia, Idaho, Indiana, Massachusetts, and Tennessee have missing data for gonorrhea in a few years.
} 
0.10 or higher, a dichotomous indicator for a BAC law of 0.08 or higher, and a dichotomous indicator for the presence of a youth zero tolerance law. For states in which the laws become effective at some point during the year, fractional values are used to represent the percentage of the year under which the law was in effect. Youth and young adults living in states with more stringent BAC laws face a higher full price of alcohol relative to youth living in less stringent states because the probability of being charged with drunk driving increases. Thus, it is expected that stricter BAC laws will reduce alcohol consumption and possibly reduce STDs.

Each model includes a number of other state-level variables to capture additional factors which may influence the gonorrhea or AIDS rate. These variables include the unemployment rate, real income per capita, the percentage of the population living in rural areas (gonorrhea only), and the percentage of the population 25 years and over that has obtained a bachelor's degree. The percentage of each state's population identifying with certain religions (Mormon, Southern Baptist, Protestant and Catholic) is also included. Lastly, all models include area and time dummies. The area dummies will help to capture any unobserved time-invariant area effects which may influence STD rates and may be correlated with the alcohol control policies. Time dummies are included to capture secular trends.

The state level variables are appended to the AIDS data based on the state or states represented by the MSA. Where a MSA crosses state lines, the variables are taken as a population weighted average from the relevant states. In the case of the dichotomous laws related to drunk driving, the MSA is assigned values from the state with the largest population in the MSA.

\section{Results}


Figures 1 and 2 show national gonorrhea and AIDS rates by age group and gender. Among youth, gonorrhea rates have shown a distinct downward trend over time, while AIDS rates peaked in the early 1990s, and have decreased since. Gonorrhea rates may be underreported by as much as fifty percent, however, the long history of reporting provides for a good indication of the true trends in the disease (CDC 2000b). It is uncertain as to whether the underreporting of diseases will present a problem for the multivariate estimation. If the underreporting is random and is uncorrelated with the included variables, the estimated coefficients will not be biased. However, if there exists systematic reporting errors that are not captured by the state dummies, then biases may occur.

\section{[FIGURE 1 ABOUT HERE]}

\section{[FIGURE 2 ABOUT HERE]}

Table 1 shows the average gonorrhea and AIDS rates along with the summary statistics for the alcohol regulatory variables and the area characteristics. Young females ages 15-19 have the highest average gonorrhea rate at 457 per 100,000 population. This average is closely followed by the rates for males and females ages 20-24 at 456 and 376 cases per 100,000 population, respectively. Young males ages 15-19 have the lowest reported rates of 332 cases per 100,000 population. The average AIDS rates are much lower than that of gonorrhea. The average male AIDS rate per 100,000 population are 14.95 and 37.35 for those ages $20-29$, and 30-34, respectively, while the corresponding rates for females are 4.42 and 7.90, respectively.

\section{[TABLE 1 ABOUT HERE]}

Tables 2 through 7 show the results of the impact of the alcohol regulatory variables on gonorrhea and AIDS rates for males and females by age group. Six regression models are presented in each table. The first is a simple OLS, the second is an OLS with lagged alcohol 
regulatory variables, the third and fourth include the lagged dependent variable or the lagged total rate treated as exogenous, and the fifth and sixth are the first-difference two stage least squares estimates (FD2SLS) with the lagged dependent variable or lagged total rate. All standard errors are adjusted for clustered by state, and all estimates are weighted by the relevant population.

The dependent variables are all in log form, as is the beer tax so that elasticities are directly estimated. In the early years of the AIDS data, some MSAs have no reported cases of AIDS. This occurs in 6 percent of the male sample and 25 percent of the female sample. In these cases, a small value ( 1 in 2 million) is used so that logs can be taken. This value is chosen to ensure that the zero cases will be represented by the smallest value possible in the data. Note that using unlogged AIDS rates as the dependent variable yields results very similar to those presented below. There are no zeros in the gonorrhea data.

\section{Gonorrhea}

In regards to the male gonorrhea rates for both age groups, a striking result arises that all models in Tables 2 and 3 show a negative and statistically significant coefficient on the beer tax (the beer tax and lagged beer tax are jointly significant in the lagged models, although at the 10 percent level). From the simple OLS models, a ten percent increase in the average state excise tax on beer will reduce the gonorrhea rate by 4.7 percent for males ages $15-19$ and by 4.1 percent for males ages 20-24. Models including the lagged tax rate give similar estimates.

[TABLE 2 ABOUT HERE]

[TABLE 3 ABOUT HERE]

The magnitude of these effects fall slightly by a range of 6 to 10 percent from the OLS in 
columns 1 and 2 to the FD2SLS estimates in columns 5 and 6. When the lagged total rate is included (column 6), a ten percent increase in the average state excise tax on beer will reduce the gonorrhea rate by 4.4 percent for males $15-19$ and by 3.7 percent for males 20-24. Estimates are slightly larger when the lagged dependent variable is included. This decrease in the elasticity is not surprising since the tax effect is calculated holding the lagged gonorrhea rate constant. That is, it represents a short-run effect which only lets tax influence the current STD rate. A long-run effect can be calculated by dividing the tax coefficient by one minus the coefficient on the lagged gonorrhea rate. For males in both age groups, the long run elasticity is -1.1 based on the estimates in column 6.

Both the long run and short run tax effects presented here are larger than those found by Chesson et al. (2000) who do take into account the endogeneity of the lagged gonorrhea rate. ${ }^{7}$ The coefficients presented in column 3 and 4 of Tables 2 and 3 demonstrate that the treatment of the lagged dependent variable matters. For example, the short run tax effect for males ages 2024 is 37 percent smaller and the long run tax effect is 40 percent smaller when the lagged dependent variable is treated as exogenous (compare columns 3 and 5). Because of the bias in the OLS models with lagged dependent variables, the remaining discussion of the results will focus primarily on the OLS models in columns 1 and 2, and the FD2SLS models in columns 5 and 6.

The availability of alcohol, as measured by the percentages of the population living in dry counties, does not appear to be important in lowering male gonorrhea rates. The same can be said for the drunk driving laws. Neither the 0.10 BAC law nor the 0.08 BAC law has an effect

\footnotetext{
${ }^{7}$ Chesson et al. present partial elasticities (the percentage change in the gonorrhea rate for a $\$ 1.00$ change in the beer tax) for youth. Converting their estimates to elasticities using the mean tax rate existing during their sample period, the tax elasticities for males $15-19$ and 20-24 are -0.36 and -0.32 , respectively.
} 
on gonorrhea rates for males, although zero tolerance laws, which are aimed at drivers under the legal drinking age, are associated with a decrease in the gonorrhea rate of males ages 15-19. Using the results from the FD2SLS estimates, teenage males living in states with a zero tolerance law have lower gonorrhea rates (by 7-8 percent) than those in states without such a law.

For brevity, Table 4 contains only the results of alcohol regulatory variables on the female gonorrhea rates for the two different age groups. Here, none of the alcohol regulatory variables that affect male rates are effective in lowering the female rates. The coefficients on the beer tax are statistically insignificant and the sign switches depending on the model. A similar statement can be made for the coefficients on percent dry. Estimates associated with the BAC laws are mixed, and the inconsistent signs and levels of significance suggest that no firm conclusions can be made and further research is warranted.

[TABLE 4 ABOUT HERE]

\section{$A I D S$}

Tables 5 and 6 show the results of the impact of the alcohol regulatory variables on AIDS rates for males ages 20-29 and 30-34, respectively. The OLS models in columns 1-2 show negative and statistically significant effects of the beer tax on AIDS rates. For the younger males, the estimates in column 1 yield a tax elasticity of -0.51 , which increases to -0.85 if the lags of the tax are included. The magnitudes are smaller for the older males, with elasticities of -0.32 and -0.64 in columns 1 and 2 , respectively. For the younger males, the tax coefficients are negative but are not statistically significant in the FD2SLS models. Here, the magnitudes are smaller than in the OLS models. The short run elasticity is -0.20 , and the long run elasticity is about -0.24. For older males, the FD2SLS coefficients are statistically insignificant and positive. Note that the coefficients on the lagged AIDS rates in all males models are small in 
magnitude (columns 3-6). This provides some evidence that a one year lag in the AIDS rate does not contribute much to this model and the OLS models in columns 1 and 2 may be the preferred specifications.

[TABLE 5 ABOUT HERE]

[TABLE 6 ABOUT HERE]

Results for the female AIDS rates in Table 7 are similar to those for males in that the beer tax coefficients are negative and statistically significant in the OLS models, but these results do not hold in the FD2SLS models. Again, the coefficients on the lagged AIDS rates are small in magnitude and in the FD2SLS models, only one coefficient of the four is statistically significant. In regards to the drunk driving laws and the percent dry, none of these alcohol policies are associated with decreased AIDS rates for youth of both genders. The one exception is that states with larger percentages of the population living in dry counties have a lower the AIDS rate among females ages 30-34. Here, every one percent increase in the percent living in dry counties is associated with a 0.07 percent decrease in the AIDS rate. Note that this result pertains only to the OLS models in columns 1-4.

\section{[TABLE 7 ABOUT HERE]}

It is somewhat surprising that the lagged AIDS rate does not have much of an influence on the current AIDS rate for both males and female. It is possible that the model is misspecified and that the one year lag is inappropriate, particularly given the difficulties in tracking the timing of HIV infection. Models were tested with a two year lag and results remained similar. Recall also that biases due to random measurement error in the alcohol variables will be exacerbated in the first differences models, possibly making these estimates unreliable. Given these problems, we treat the AIDS results as suggestive and not definitive. Clearly, further research is needed. 


\section{Discussion}

One important risk factor in determining risky sexual behaviors among youth is alcohol consumption. Given the strong link between alcohol use and risky sexual practices, this paper seeks to determine whether policies designed to reduce the consumption of alcohol may succeed in reducing rates of STDs among youth as well. The results of multivariate regressions indicate that higher beer taxes and the presence of zero tolerance laws are associated with reductions in the male gonorrhea rates, although other alcohol policies such as BAC laws and dry counties appear to have no effects. The results also suggest that AIDS rates may be reduced with higher beer taxes, although this result is not robust to the first-differenced two stage least square models which include the lagged AIDS rate. Future research should focus on a similar study of HIV rates, rather than AIDS cases, where the alcohol control variables can be matched more closely to the risky sexual act and the appropriate date of transmission.

In addition to the problems with matching the alcohol control variables to the transmission date of HIV, there are some other limitations to this research that must be considered. First, this research does not provide much policy guidance on ways to reduce gonorrhea rates for females. This is certainly a direction for future research. Second, by 1999,

all states had enacted zero tolerance laws, and now these laws are no longer a viable policy tool which can be used to further reduce the teenage male gonorrhea rate. Third, while the state dummies help capture time-invariant state-level factors which may be correlated with alcohol policies and STDs, time-variant factors may still remain in the error term and have the potential to bias the results. However, it is difficult to predict the direction of any such bias.

The results in the paper presented here suggest that male gonorrhea rates, and by 
inference, the sexual behaviors that put males at risk for contracting STDs, can be reduced through the manipulation of alcohol policies that reduce alcohol consumption. To place these results in the broader context of the existing literature, recall that firm conclusions regarding the nature of the causal relationship between risky sexual behaviors and alcohol consumption are still in question. However, two results appear to be prevalent in this literature regarding teenage behaviors: The first is that alcohol use lowers contraception use, particularly for males, and the second is that alcohol use appears to have no causal impact on the probability of having sex. If these conclusions are true, then the notion that gonorrhea and AIDS rates may be reduced with policies such as higher beer taxes or strict drunk driving laws is in line with the consensus findings, as STDs are preventable by both abstinence and contraception in the form of condoms. It is highly plausible that alcohol control measures reduce alcohol consumption, increase condom usage, and thereby reduce the transmission of STDs. These links allow for the observed negative relationship between some alcohol regulatory variables and STD rates. 


\section{References}

Baltagi, B. H. (2001). Econometric Analysis of Panel Data. England: John Wiley and Sons.

Bartlett, J. G. and Gallant, J.E. (2003). Medical Management of HIV Infection. Baltimore: Johns Hopkins University.

Beer Institute (various years). Brewers' Almanac. New York: United States Brewers Foundation.

Bertrand, M., Duflo, E. and Mullainathan, S. (2004) How Much Should We Trust Differencesin-Differences Estimates? Quarterly Journal of Economics, 119:1, 249-75.

Carpenter, C. (in press) Youth Alcohol Use and Risky Sexual Behavior: Evidence from Underage Drunk Driving Laws. Journal of Health Economics.

Carpenter, C. (2004) How do Zero Tolerance Drunk Driving Laws Work? Journal of Health Economics, 23:1, 61-83.

Centers for Disease Control and Prevention. (2003). Sexually Transmitted Disease Surveillance, 2002. Atlanta, GA: U.S. Department of Health and Human Services, Centers for Disease Control and Prevention.

Centers for Disease Control and Prevention. (2002). Young People at Risk: HIV/AIDS among America's Youth. Atlanta, GA: U.S. Department of Health and Human Services, Centers for Disease Control and Prevention.

Centers for Disease Control and Prevention. (2000a). Summary of Notifiable Diseases, United States, 2000. Mortality and Morbidity Weekly Report, 49.

Centers for Disease Control and Prevention. (2000b) Tracking the Hidden Epidemics, Trends in STDs in the United States 2000. Atlanta, GA: U.S. Department of Health and Human Services, Centers for Disease Control and Prevention..

Centers for Disease Control and Prevention. (1992). 1993 Revised Classification System for HIV Infection and Expanded Surveillance Case Definition for AIDS Among Adolescents and Adults. Mortality and Morbidity Weekly Report, 41, No RR17;001.

Chesson, H., Harrison, P. and Kassler, W. J. (2000). Sex Under the Influence: The Effect of Alcohol Policy on Sexually Transmitted Disease Rates in the U.S. Journal of Law and Economics, 43:1, 215-238.

Cook, P. J. and Moore, M.J. (2000). Alcohol. In A.J. Culyer and J.P. Newhouse (Eds.), Handbook of Health Economics Vol 1B. New York: North-Holland, 1629-1673.

Dee, T. (2001). The Effects of Minimum Legal Drinking Ages on Teen Childbearing. Journal of Human Resources, 36, 823-838.

Donovan, C. and McEwan, R. (1995). A Review of the Literature Examining the Relationship Between Alcohol Use and HIV-Related Sexual Risk-Taking in Young People. Addiction, 90:3, 319-328.

Fergusson, D.M. and Lynskey, M.T. (1996). Alcohol Misuse and Adolescent Sexual Behaviors and Risk Taking. Pediatrics 98, 91-96. 
Graves, K.L. and Leigh B.L. (1995). The Relationship of Substance Use to Sexual Activity among Young Adults in the United States. Family Planning Perspectives 27, 18-33

Grossman, M., Chaloupka, F.J. and Sirtalan, I. (1998). An Empirical Analysis of Alcohol Addiction: Results from the Monitoring the Future Panels. Economic Inquiry, 36:1, 39-48.

Grossman, M., Chaloupka, F.J., Saffer, H. and Laixuthai, A. (1994). Effects of alcohol price policy on youth: A summary of economic research. Journal of Research on Adolescence, 4, 347-364.

Grossman, M., Kaestner, R. and Markowitz, S. (in press). Get High and Get Stupid: The Effect of Alcohol and Marijuana Use on Teen Sexual Behavior. Review of the Economics of the Household.

Grossman, M. and Markowitz, S. (in press). I Did What Last Night?! Adolescent Risky Sexual Behaviors and Substance Use. Eastern Economic Journal.

Jobson's Liquor Handbook. (various years). Jobson Publishing Corporation, New York, NY.

Kaestner, R. and Joyce, T. (2001). Alcohol and Drug Use: Risk Factors for Unintended Pregnancy. In . in M. Grossman and C. Hsieh (Eds.), The Economic Analysis Of Substance Use And Abuse: The Experience of Developed Countries and Lessons for Developing Countries, Edward Elgar Limited, United Kingdom.

Laumann, E. O., Gagnon, J.H., Michael, R.T. and Michaels, S. (1994). The Social Organization of Sexuality: Sexual Practices in the United States. Chicago: The University of Chicago Press.

Leigh, B. C. and Stall, R. (1993). Substance Use and Risky Sexual Behavior for Exposure to HIV, Issues in Methodology, Interpretation and Prevention. American Psychologist. 48:10, 1035-1044.

Leung, S. F. and Phelps, C. E. (1993). 'My Kingdom for a Drink....?' A Review of the Price Sensitivity of Demand for Alcoholic Beverages in G. Bloss and M Hilton (Eds.), Economic and Socioeconomic Issues in the Prevention of Alcohol-Related Problems. U.S. Government Printing Office, 1993.

Moore, M. J and Cook P. J. (1985). Habit and Heterogeneity in the Youthful Demand for Alcohol. NBER working paper \#5152.

Nickell, S. J. (1981).Biases in Dynamic Models with Fixed Effects. Econometrica, 49:6, $1417-$ 1426

Rashad, I. and Kaestner, R. (2004). Teenage Sex, Drugs and Alcohol Use: Problems Identifying the Cause of Risky Behaviors. Journal of Health Economics, 23:3, 493-503.

Rees, D. I., Argys, L. M. and Averett, S.L. (2001). New Evidence on the Relationship between Substance Use and Adolescent Sexual Behavior. Journal of Health Economics, 20:5, 835-845.

Sen, B. (2002). Does Alcohol-Use Increase the Risk of Sexual Intercourse Among Adolescents? Evidence From the NLSY97. Journal of Health Economics, 21:6, 1085-1093. 
Scribner, R. A., Cohen, D. A. and Farley, T.A.(1998). A Geographic Relation Between Alcohol Availability and Gonorrhea Rates. Sexually Transmitted Diseases, 25:10, 544-548.

Strunin, L. and Hingson, R. (1992). Alcohol, Drugs, and Adolescent Sexual Behavior. International Journal of Addictions 27, 129-146. 
Figure 1, National Gonorrhea Rates 1981-2001

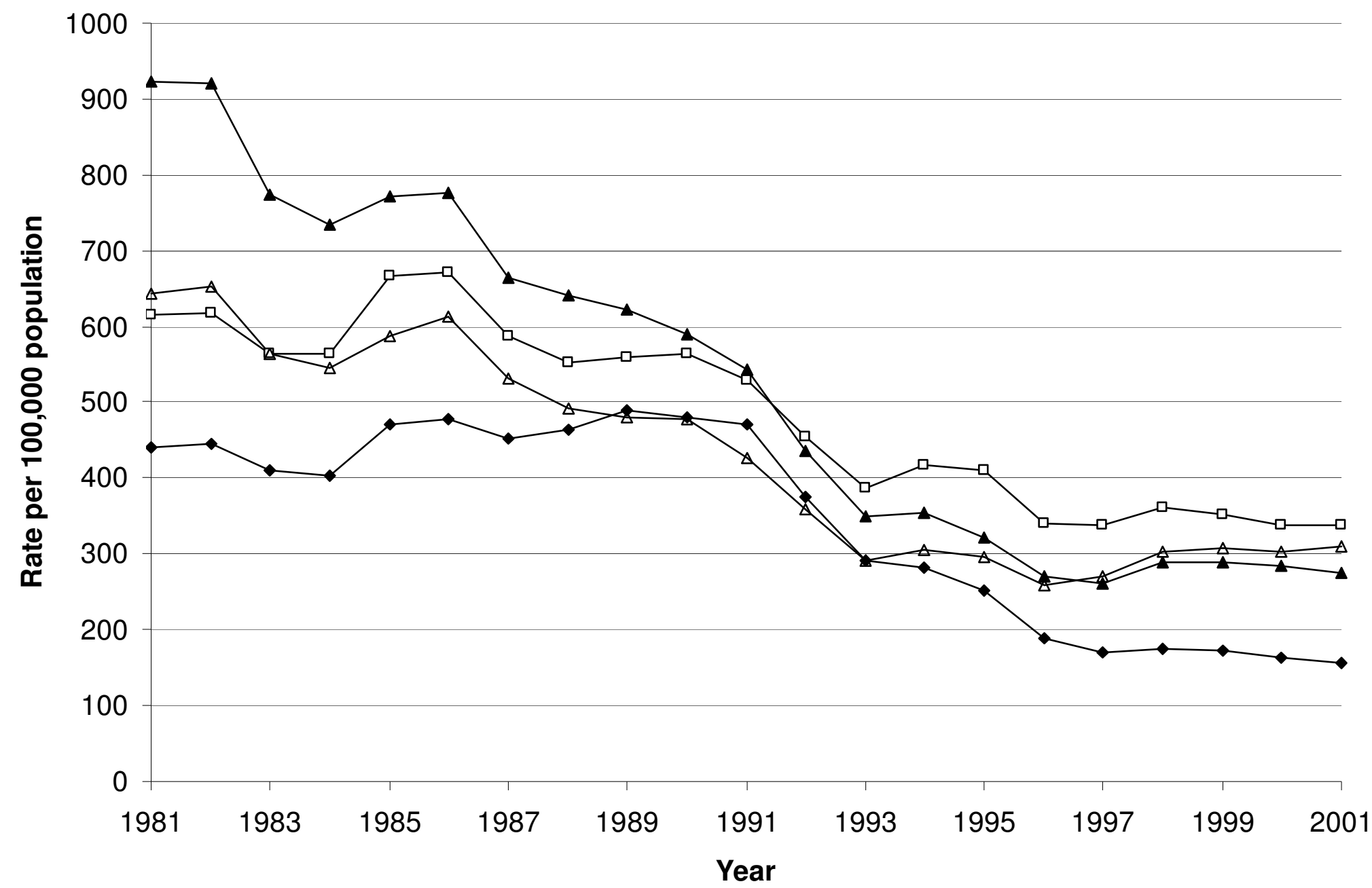

$\rightarrow$ Males 15-19 $\rightarrow-$ Females 15-19 $\rightarrow$ Males 20-24 $\triangle$ Females 20-24 
Figure 2, New AIDS cases per 100,000 population, 1982-2001

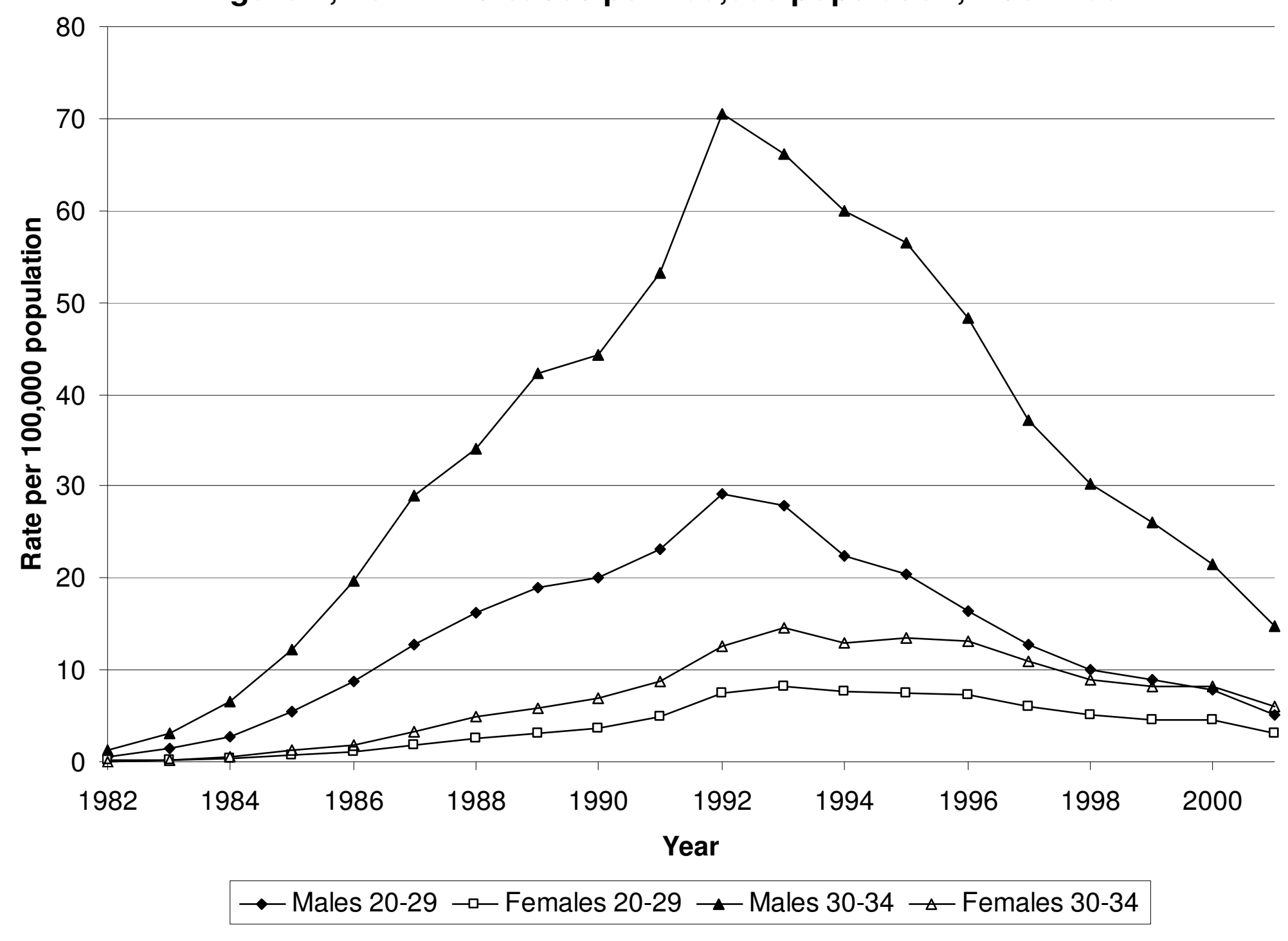


Table 1

Summary Statistics

\begin{tabular}{|c|c|c|c|}
\hline Variable & Definition & \begin{tabular}{|c|} 
Mean, Std Dev \\
(Gonorrhea \\
Sample: States)
\end{tabular} & $\begin{array}{l}\text { Mean, Std Dev } \\
\text { (AIDS Sample: } \\
\text { MSAs) }\end{array}$ \\
\hline $\begin{array}{l}\text { Male gonorrhea rate, ages 15-19 } \\
\text { (Log rate) }\end{array}$ & $\begin{array}{l}\text { Gonorrhea rate for males ages } 15-19 \text { per } 100,000 \\
\text { population ages } 15-19 \text { in state. }\end{array}$ & \begin{tabular}{|c|}
$331.81,524.99$ \\
$(5.08,1.36)$
\end{tabular} & \\
\hline $\begin{array}{l}\text { Male gonorrhea rate, ages } 20-24 \\
\text { (Log rate) }\end{array}$ & $\begin{array}{l}\text { Gonorrhea rate for males ages } 20-24 \text { per } 100,000 \\
\text { population ages } 20-24 \text { in state. }\end{array}$ & $\begin{array}{c}456.13,566.75 \\
(5.56,1.19)\end{array}$ & \\
\hline $\begin{array}{l}\text { Female gonorrhea rate, ages } 15-19 \\
\text { (Log rate) }\end{array}$ & $\begin{array}{l}\text { Gonorrhea rate for females ages } 15-19 \text { per } \\
100,000 \text { population ages } 15-19 \text { in state. }\end{array}$ & $\begin{array}{c}456.69,485.58 \\
(5.64,1.13)\end{array}$ & \\
\hline $\begin{array}{l}\text { Female gonorrhea rate, ages } 20-24 \\
\text { (Log rate) }\end{array}$ & $\begin{array}{l}\text { Gonorrhea rate for females ages } 20-24 \text { per } \\
100,000 \text { population ages } 20-24 \text { in state. }\end{array}$ & $\begin{array}{c}376.46,338.30 \\
(5.49,1.09)\end{array}$ & \\
\hline $\begin{array}{l}\text { Male AIDS rate, ages } 20-29 \\
\text { (Log rate) }\end{array}$ & $\begin{array}{l}\text { AIDS rate for males ages } 20-29 \text { per } 100,000 \\
\text { population ages } 20-29 \text { in MSA. }\end{array}$ & & $\begin{array}{c}14.95,13.82 \\
(2.22,1.24)\end{array}$ \\
\hline $\begin{array}{l}\text { Male AIDS rate, ages 30-34 } \\
\text { (Log rate) }\end{array}$ & $\begin{array}{l}\text { AIDS rate for males ages } 30-34 \text { per } 100,000 \\
\text { population ages } 20-29 \text { in MSA. }\end{array}$ & & $\begin{array}{l}37.35,36.26 \\
(3.14,1.24)\end{array}$ \\
\hline $\begin{array}{l}\text { Female AIDS rate, ages } 20-29 \\
\text { (Log rate) }\end{array}$ & $\begin{array}{l}\text { AIDS rate for females ages } 20-29 \text { per } 100,000 \\
\text { population ages 30-34 in MSA. }\end{array}$ & & $\begin{array}{c}4.42,6.60 \\
(0.40,1.83)\end{array}$ \\
\hline $\begin{array}{l}\text { Female AIDS rate, ages } 30-34 \\
\text { (Log rate) }\end{array}$ & $\begin{array}{l}\text { AIDS rate for females ages } 30-34 \text { per } 100,000 \\
\text { population ages } 30-34 \text { in MSA. }\end{array}$ & & $\begin{array}{l}7.90,12.09 \\
(0.77,2.12)\end{array}$ \\
\hline $\begin{array}{l}\text { Real beer tax } \\
\text { (Log real beer tax) }\end{array}$ & Real state and federal excise tax per gallon of beer & $\begin{array}{c}0.49,0.14 \\
(-0.75,0.27)\end{array}$ & $\begin{array}{c}0.54,0.23 \\
(-0.69,0.37)\end{array}$ \\
\hline Percent dry & $\begin{array}{l}\text { Percentage of state population living in counties } \\
\text { that are dry for beer. }\end{array}$ & $4.09,9.49$ & $4.28,7.87$ \\
\hline 0.10 BAC law & $\begin{array}{l}\text { Dichotomous variable that equals } 1 \text { if per se } \\
\text { illegal to drive with a blood alcohol concentration } \\
\text { of } 0.10 \text { or greater }\end{array}$ & $0.74,0.43$ & $0.60,0.48$ \\
\hline 0.08 BAC law & $\begin{array}{l}\text { Dichotomous variable that equals } 1 \text { if per se } \\
\text { illegal to drive with a blood alcohol concentration } \\
\text { of } 0.08 \text { or greater }\end{array}$ & $0.16,0.36$ & $0.04,0.19$ \\
\hline Zero tolerance law & $\begin{array}{l}\text { Dichotomous variable that equals } 1 \text { if state has } \\
\text { zero tolerance laws for youth underage drinking } \\
\text { and driving }\end{array}$ & $0.43,0.49$ & $0.11,0.30$ \\
\hline Unemployment & Unemployment rate & $5.75,2.02$ & $6.90,1.91$ \\
\hline Real income & Per capita income, adjusted for inflation & $145.19,25.25$ & $136.06,20.89$ \\
\hline Percent rural & Percentage of state population living in rural areas & $30.04,15.19$ & Not Applicable \\
\hline College degree & $\begin{array}{l}\text { Percentage of state population } 25 \text { years and older } \\
\text { that has graduated from a 4-year college }\end{array}$ & $21.37,5.05$ & $18.07,3.95$ \\
\hline Mormon & Percentage of state population Mormon & $2.98,10.09$ & $1.47,6.74$ \\
\hline Southern Baptist & Percentage of state population Southern Baptist & $7.11,9.90$ & $7.79,9.48$ \\
\hline Protestant & Percentage of state population Protestant & $21.65,9.87$ & $19.73,7.61$ \\
\hline Catholic & Percentage of state population Catholic & $19.19,12.66$ & $20.48,12.80$ \\
\hline
\end{tabular}

Note: Means for independent variables used in the AIDS regressions are lagged 8 years. 
Table 2

Gonorrhea

Males Age 15-19

\begin{tabular}{|c|c|c|c|c|c|c|}
\hline & $\begin{array}{l}\text { OLS } \\
(1)\end{array}$ & $\begin{array}{c}\text { Lagged } \\
\text { OLS } \\
\text { (2) }\end{array}$ & $\begin{array}{l}\text { Lagged } \\
\text { Dependent } \\
\text { Variable } \\
\text { OLS } \\
\text { (3) }\end{array}$ & $\begin{array}{c}\text { Lagged } \\
\text { Total } \\
\text { Rate } \\
\text { OLS } \\
(4)\end{array}$ & $\begin{array}{l}\text { Lagged } \\
\text { Dependent } \\
\text { Variable } \\
\text { FD2SLS } \\
\text { (5) }\end{array}$ & $\begin{array}{c}\text { Lagged } \\
\text { Total } \\
\text { Rate } \\
\text { FD2SLS } \\
\text { (6) }\end{array}$ \\
\hline Lagged male gonorrhea rate & & & $\begin{array}{r}0.639 \\
(25.14)\end{array}$ & & $\begin{array}{c}0.464 \\
(2.35)\end{array}$ & \\
\hline Lagged total rate & & & & $\begin{array}{r}0.710 \\
(25.42)\end{array}$ & & $\begin{array}{c}0.588 \\
(2.22)\end{array}$ \\
\hline Log beer tax & $\begin{array}{l}-0.471 \\
(-2.02)\end{array}$ & $\begin{array}{l}-0.355 \\
(-1.07)\end{array}$ & $\begin{array}{l}-0.278 \\
(-3.06)\end{array}$ & $\begin{array}{l}-0.427 \\
(-4.75)\end{array}$ & $\begin{array}{r}-0.467 \\
(-2.34)\end{array}$ & $\begin{array}{l}-0.441 \\
(-2.10)\end{array}$ \\
\hline Lag log beer tax & & $\begin{array}{l}-0.128 \\
(-0.64)\end{array}$ & & & & \\
\hline Percent dry & $\begin{array}{l}-0.025 \\
(-1.54)\end{array}$ & $\begin{array}{l}-0.003 \\
(-0.22)\end{array}$ & $\begin{array}{l}-0.010 \\
(-1.30)\end{array}$ & $\begin{array}{l}-0.013 \\
(-1.64)\end{array}$ & $\begin{array}{c}0.014 \\
(0.79)\end{array}$ & $\begin{array}{r}0.017 \\
(0.89)\end{array}$ \\
\hline Lag percent dry & & $\begin{array}{l}-0.026 \\
(-1.77)\end{array}$ & & & & \\
\hline 0.10 BAC law & $\begin{array}{l}-0.005 \\
(-0.05)\end{array}$ & $\begin{array}{c}0.003 \\
(0.03)\end{array}$ & $\begin{array}{l}-0.034 \\
(-0.72)\end{array}$ & $\begin{array}{c}0.032 \\
(0.68)\end{array}$ & $\begin{array}{r}0.135 \\
(1.48)\end{array}$ & $\begin{array}{c}0.126 \\
(1.38)\end{array}$ \\
\hline 0.08 BAC law & $\begin{array}{l}-0.145 \\
(-1.03)\end{array}$ & $\begin{array}{l}-0.138 \\
(-0.95)\end{array}$ & $\begin{array}{l}-0.077 \\
(-1.30)\end{array}$ & $\begin{array}{c}0.018 \\
(0.30)\end{array}$ & $\begin{array}{r}0.175 \\
(1.63)\end{array}$ & $\begin{array}{r}0.181 \\
(1.63)\end{array}$ \\
\hline Zero tolerance law & $\begin{array}{l}-0.083 \\
(-1.50)\end{array}$ & $\begin{array}{l}-0.082 \\
(-1.49)\end{array}$ & $\begin{array}{l}-0.071 \\
(-2.63)\end{array}$ & $\begin{array}{l}-0.071 \\
(-2.66)\end{array}$ & $\begin{array}{l}-0.084 \\
(-2.66)\end{array}$ & $\begin{array}{c}-0.074 \\
(-2.41)\end{array}$ \\
\hline Unemployment & $\begin{array}{c}-0.039 \\
(-1.49)\end{array}$ & $\begin{array}{c}-0.040 \\
(-1.54)\end{array}$ & $\begin{array}{l}-0.011 \\
(-1.34)\end{array}$ & $\begin{array}{c}-0.018 \\
(-2.21)\end{array}$ & $\begin{array}{c}0.006 \\
(0.41)\end{array}$ & $\begin{array}{c}0.006 \\
(0.45)\end{array}$ \\
\hline Real income & $\begin{array}{c}0.015 \\
(2.58)\end{array}$ & $\begin{array}{c}0.015 \\
(2.60)\end{array}$ & $\begin{array}{c}0.006 \\
(3.36)\end{array}$ & $\begin{array}{r}0.007 \\
(3.79)\end{array}$ & $\begin{array}{c}0.002 \\
(0.53)\end{array}$ & $\begin{array}{r}0.003 \\
(0.78)\end{array}$ \\
\hline Percent rural & $\begin{array}{r}0.031 \\
(1.69)\end{array}$ & $\begin{array}{c}0.030 \\
(1.65)\end{array}$ & $\begin{array}{c}0.010 \\
(1.65)\end{array}$ & $\begin{array}{r}0.016 \\
(2.58)\end{array}$ & $\begin{array}{c}0.005 \\
(0.31)\end{array}$ & $\begin{array}{c}0.008 \\
(0.54)\end{array}$ \\
\hline College degree & $\begin{array}{c}0.002 \\
(0.24)\end{array}$ & $\begin{array}{c}0.002 \\
(0.24)\end{array}$ & $\begin{array}{l}-0.0003 \\
(-0.04)\end{array}$ & $\begin{array}{l}-0.002 \\
(-0.30)\end{array}$ & $\begin{array}{c}0.003 \\
(0.41)\end{array}$ & $\begin{array}{r}0.003 \\
(0.34)\end{array}$ \\
\hline Percent Mormon & $\begin{array}{c}0.033 \\
(0.58)\end{array}$ & $\begin{array}{c}0.034 \\
(0.58)\end{array}$ & $\begin{array}{c}0.031 \\
(0.83)\end{array}$ & $\begin{array}{l}-0.04 \\
(-1.10)\end{array}$ & $\begin{array}{l}-0.016 \\
(-0.47)\end{array}$ & $\begin{array}{c}-0.026 \\
(-0.95)\end{array}$ \\
\hline Percent Southern Baptist & $\begin{array}{c}0.03 \\
(0.96)\end{array}$ & $\begin{array}{c}0.033 \\
(1.02)\end{array}$ & $\begin{array}{c}0.014 \\
(0.76)\end{array}$ & $\begin{array}{r}0.017 \\
(0.91)\end{array}$ & $\begin{array}{l}-0.025 \\
(-1.12)\end{array}$ & $\begin{array}{c}-0.019 \\
(-0.81)\end{array}$ \\
\hline Percent Protestant & $\begin{array}{l}-0.037 \\
(-2.26)\end{array}$ & $\begin{array}{l}-0.036 \\
(-2.20)\end{array}$ & $\begin{array}{c}0.003 \\
(0.42)\end{array}$ & $\begin{array}{c}0.004 \\
(0.52)\end{array}$ & $\begin{array}{c}0.019 \\
(1.98)\end{array}$ & $\begin{array}{r}0.017 \\
(1.76)\end{array}$ \\
\hline Percent Catholic & $\begin{array}{l}-0.043 \\
(-1.49)\end{array}$ & $\begin{array}{l}-0.043 \\
(-1.49)\end{array}$ & $\begin{array}{l}-0.011 \\
(-1.52)\end{array}$ & $\begin{array}{l}-0.017 \\
(-2.47)\end{array}$ & $\begin{array}{l}-0.032 \\
(-2.13)\end{array}$ & $\begin{array}{l}-0.026 \\
(-1.36)\end{array}$ \\
\hline F-test: beer tax, lag beer tax & & $\begin{array}{c}2.89 \\
{[0.065]}\end{array}$ & & & & \\
\hline $\begin{array}{l}\text { F-test: percent dry, lag percent } \\
\text { dry }\end{array}$ & & $\begin{array}{l}1.67 \\
{[0.199]}\end{array}$ & & & & \\
\hline R-squared & 0.928 & 0.928 & 0.958 & 0.959 & -- & -- \\
\hline
\end{tabular}

Note: t-statistics in parentheses, p-values in brackets, and intercept not shown. Standard errors are clustered by state. All models include state and year dummies and are weighted by the state population. $\mathrm{N}=950$. 
Table 3

Gonorrhea

Males Age 20-24

\begin{tabular}{|c|c|c|c|c|c|c|}
\hline & $\begin{array}{l}\text { OLS } \\
(1)\end{array}$ & $\begin{array}{c}\text { Lagged } \\
\text { OLS } \\
\text { (2) }\end{array}$ & $\begin{array}{l}\text { Lagged } \\
\text { Dependent } \\
\text { Variable } \\
\text { OLS } \\
\text { (3) }\end{array}$ & $\begin{array}{c}\text { Lagged } \\
\text { Total } \\
\text { Rate } \\
\text { OLS } \\
(4)\end{array}$ & $\begin{array}{l}\text { Lagged } \\
\text { Dependent } \\
\text { Variable } \\
\text { FD2SLS } \\
\text { (5) }\end{array}$ & $\begin{array}{l}\text { Lagged } \\
\text { Total } \\
\text { Rate } \\
\text { FD2SLS } \\
\text { (6) }\end{array}$ \\
\hline Lagged male gonorrhea rate & & & $\begin{array}{r}0.635 \\
(24.18)\end{array}$ & & $\begin{array}{c}0.649 \\
(2.83)\end{array}$ & \\
\hline Lagged total rate & & & & $\begin{array}{r}0.663 \\
(24.41)\end{array}$ & & $\begin{array}{c}0.656 \\
(2.40)\end{array}$ \\
\hline Log beer tax & $\begin{array}{l}-0.411 \\
(-2.12)\end{array}$ & $\begin{array}{l}-0.410 \\
(-1.28)\end{array}$ & $\begin{array}{l}-0.237 \\
(-2.79)\end{array}$ & $\begin{array}{c}-0.310 \\
(-3.66)\end{array}$ & $\begin{array}{l}-0.378 \\
(-2.20)\end{array}$ & $\begin{array}{c}-0.368 \\
(-2.08)\end{array}$ \\
\hline Lag log beer tax & & $\begin{array}{c}0.004 \\
(0.02)\end{array}$ & & & & \\
\hline Percent dry & $\begin{array}{l}-0.044 \\
(-1.98)\end{array}$ & $\begin{array}{l}-0.024 \\
(-1.45)\end{array}$ & $\begin{array}{l}-0.021 \\
(-2.60)\end{array}$ & $\begin{array}{l}-0.023 \\
(-2.92)\end{array}$ & $\begin{array}{c}0.016 \\
(0.71)\end{array}$ & $\begin{array}{r}0.017 \\
(0.80)\end{array}$ \\
\hline Lag percent dry & & $\begin{array}{l}-0.024 \\
(-1.54)\end{array}$ & & & & \\
\hline 0.10 BAC law & $\begin{array}{c}0.018 \\
(0.17)\end{array}$ & $\begin{array}{c}0.026 \\
(0.24)\end{array}$ & $\begin{array}{l}-0.042 \\
(-0.92)\end{array}$ & $\begin{array}{l}-0.0003 \\
(-0.01)\end{array}$ & $\begin{array}{r}0.101 \\
(1.08)\end{array}$ & $\begin{array}{c}0.110 \\
(1.16)\end{array}$ \\
\hline 0.08 BAC law & $\begin{array}{l}-0.015 \\
(-0.11)\end{array}$ & $\begin{array}{l}-0.004 \\
(-0.03)\end{array}$ & $\begin{array}{l}-0.042 \\
(-0.74)\end{array}$ & $\begin{array}{c}0.022 \\
(0.38)\end{array}$ & $\begin{array}{r}0.105 \\
(1.00)\end{array}$ & $\begin{array}{c}0.118 \\
(1.10)\end{array}$ \\
\hline Zero tolerance law & $\begin{array}{l}-0.066 \\
(-1.25)\end{array}$ & $\begin{array}{l}-0.065 \\
(-1.22)\end{array}$ & $\begin{array}{l}-0.044 \\
(-1.72)\end{array}$ & $\begin{array}{l}-0.054 \\
(-2.11)\end{array}$ & $\begin{array}{c}-0.029 \\
(-1.08)\end{array}$ & $\begin{array}{l}-0.03 \\
(-1.09)\end{array}$ \\
\hline Unemployment & $\begin{array}{l}-0.047 \\
(-2.22)\end{array}$ & $\begin{array}{r}-0.049 \\
(-2.33)\end{array}$ & $\begin{array}{l}-0.016 \\
(-2.02)\end{array}$ & $\begin{array}{l}-0.022 \\
(-2.87)\end{array}$ & $\begin{array}{c}0.025 \\
(1.74)\end{array}$ & $\begin{array}{c}0.023 \\
(1.59)\end{array}$ \\
\hline Real income & $\begin{array}{r}0.017 \\
(2.94)\end{array}$ & $\begin{array}{r}0.017 \\
(2.98)\end{array}$ & $\begin{array}{c}0.008 \\
(4.45)\end{array}$ & $\begin{array}{c}0.008 \\
(4.29)\end{array}$ & $\begin{array}{c}0.002 \\
(0.35)\end{array}$ & $\begin{array}{c}0.002 \\
(0.37)\end{array}$ \\
\hline Percent rural & $\begin{array}{r}0.029 \\
(1.45)\end{array}$ & $\begin{array}{c}0.028 \\
(1.42)\end{array}$ & $\begin{array}{r}0.012 \\
(1.93)\end{array}$ & $\begin{array}{r}0.013 \\
(2.12)\end{array}$ & $\begin{array}{c}0.011 \\
(0.63)\end{array}$ & $\begin{array}{c}0.010 \\
(0.57)\end{array}$ \\
\hline College degree & $\begin{array}{r}0.013 \\
(1.20)\end{array}$ & $\begin{array}{c}0.013 \\
(1.20)\end{array}$ & $\begin{array}{r}0.004 \\
(0.52)\end{array}$ & $\begin{array}{r}0.004 \\
(0.62)\end{array}$ & $\begin{array}{c}0.002 \\
(0.24)\end{array}$ & $\begin{array}{l}0.0002 \\
(0.03)\end{array}$ \\
\hline Percent Mormon & $\begin{array}{r}0.097 \\
(1.97)\end{array}$ & $\begin{array}{c}0.095 \\
(1.89)\end{array}$ & $\begin{array}{r}0.061 \\
(1.67)\end{array}$ & $\begin{array}{r}0.021 \\
(0.57)\end{array}$ & $\begin{array}{l}0.044 \\
(2.32)\end{array}$ & $\begin{array}{c}0.044 \\
(2.30)\end{array}$ \\
\hline Percent Southern Baptist & $\begin{array}{c}0.058 \\
(1.28)\end{array}$ & $\begin{array}{r}0.060 \\
(1.30)\end{array}$ & $\begin{array}{c}0.028 \\
(1.47)\end{array}$ & $\begin{array}{c}0.026 \\
(1.38)\end{array}$ & $\begin{array}{l}-0.0002 \\
(-0.01)\end{array}$ & $\begin{array}{l}-0.005 \\
(-0.19)\end{array}$ \\
\hline Percent Protestant & $\begin{array}{l}-0.024 \\
(-1.34)\end{array}$ & $\begin{array}{l}-0.024 \\
(-1.38)\end{array}$ & $\begin{array}{c}0.008 \\
(1.06)\end{array}$ & $\begin{array}{r}0.006 \\
(0.90)\end{array}$ & $\begin{array}{c}0.022 \\
(2.37)\end{array}$ & $\begin{array}{c}0.019 \\
(1.97)\end{array}$ \\
\hline Percent Catholic & $\begin{array}{l}-0.049 \\
(-1.90)\end{array}$ & $\begin{array}{c}-0.049 \\
(-1.87)\end{array}$ & $\begin{array}{c}-0.013 \\
(-1.88)\end{array}$ & $\begin{array}{l}-0.018 \\
(-2.63)\end{array}$ & $\begin{array}{l}-0.012 \\
(-0.96)\end{array}$ & $\begin{array}{l}-0.012 \\
(-0.76)\end{array}$ \\
\hline F-test: beer tax, lag beer tax & & $\begin{array}{c}2.49 \\
{[0.093]}\end{array}$ & & & & \\
\hline $\begin{array}{l}\text { F-test: percent dry, lag percent } \\
\text { dry }\end{array}$ & & $\begin{array}{l}2.03 \\
{[0.143]}\end{array}$ & & & & \\
\hline $\mathrm{R}$-squared & 0.916 & 0.916 & 0.95 & 0.95 & -- & -- \\
\hline
\end{tabular}

Note: t-statistics in parentheses, p-values in brackets, and intercept not shown. Standard errors are clustered by state. All models include state and year dummies and are weighted by the state population. $\mathrm{N}=950$. 
Table 4, Gonorrhea, Females

\begin{tabular}{|c|c|c|c|c|c|c|}
\hline & OLS & $\begin{array}{c}\text { Lagged } \\
\text { OLS }\end{array}$ & $\begin{array}{c}\text { Lagged } \\
\text { Dependent } \\
\text { Variable } \\
\text { OLS }\end{array}$ & $\begin{array}{c}\text { Lagged } \\
\text { Total } \\
\text { Rate } \\
\text { OLS } \\
\end{array}$ & $\begin{array}{c}\text { Lagged } \\
\text { Dependent } \\
\text { Variable } \\
\text { FD2SLS }\end{array}$ & $\begin{array}{c}\text { Lagged } \\
\text { Total } \\
\text { Rate } \\
\text { FD2SLS }\end{array}$ \\
\hline Females ages $15-19$ & (1) & (2) & (3) & (4) & (5) & $(6)$ \\
\hline Lagged female gonorrhea rate & & & $\begin{array}{r}0.700 \\
(29.23)\end{array}$ & & $\begin{array}{c}0.548 \\
(2.88)\end{array}$ & \\
\hline Lagged total rate & & & & $\begin{array}{r}0.704 \\
(28.43)\end{array}$ & & $\begin{array}{c}0.53 \\
(2.28)\end{array}$ \\
\hline Log beer tax & $\begin{array}{c}0.027 \\
(0.12)\end{array}$ & $\begin{array}{c}-0.004 \\
(-0.01)\end{array}$ & $\begin{array}{c}-0.052 \\
(-0.66)\end{array}$ & $\begin{array}{c}0.070 \\
(0.88)\end{array}$ & $\begin{array}{c}0.060 \\
(0.28)\end{array}$ & $\begin{array}{c}0.066 \\
(0.31)\end{array}$ \\
\hline Lag log beer tax & & $\begin{array}{c}0.040 \\
(0.15)\end{array}$ & & & & \\
\hline Percent dry & $\begin{array}{c}-0.010 \\
(-0.54)\end{array}$ & $\begin{array}{c}0.010 \\
(0.67)\end{array}$ & $\begin{array}{c}-0.002 \\
(-0.28)\end{array}$ & $\begin{array}{c}0.002 \\
(0.22)\end{array}$ & $\begin{array}{c}0.025 \\
(1.79)\end{array}$ & $\begin{array}{c}0.024 \\
(1.68)\end{array}$ \\
\hline Lag percent dry & & $\begin{array}{l}-0.024 \\
(-1.85)\end{array}$ & & & & \\
\hline 0.10 BAC law & $\begin{array}{c}-0.156 \\
(-1.78)\end{array}$ & $\begin{array}{c}-0.149 \\
(-1.66)\end{array}$ & $\begin{array}{l}-0.082 \\
(-2.00)\end{array}$ & $\begin{array}{l}-0.120 \\
(-2.90)\end{array}$ & $\begin{array}{c}0.121 \\
(1.62)\end{array}$ & $\begin{array}{c}0.130 \\
(1.74)\end{array}$ \\
\hline 0.08 BAC law & $\begin{array}{c}-0.334 \\
(-2.56)\end{array}$ & $\begin{array}{c}-0.323 \\
(-2.50)\end{array}$ & $\begin{array}{c}-0.122 \\
(-2.34)\end{array}$ & $\begin{array}{c}-0.173 \\
(-3.28)\end{array}$ & $\begin{array}{c}0.169 \\
(1.75)\end{array}$ & $\begin{array}{c}0.175 \\
(1.87)\end{array}$ \\
\hline Zero tolerance law & $\begin{array}{c}-0.038 \\
(-0.71)\end{array}$ & $\begin{array}{c}-0.036 \\
(-0.68)\end{array}$ & $\begin{array}{c}-0.030 \\
(-1.30)\end{array}$ & $\begin{array}{c}-0.026 \\
(-1.11)\end{array}$ & $\begin{array}{c}0.010 \\
(0.25)\end{array}$ & $\begin{array}{c}0.001 \\
(0.01)\end{array}$ \\
\hline F-test: beer tax, lag beer tax & & $\begin{array}{c}0.02 \\
{[0.984]}\end{array}$ & & & & \\
\hline $\begin{array}{l}\text { F-test: percent dry, lag percent } \\
\text { dry }\end{array}$ & & $\begin{array}{c}1.87 \\
{[0.164]} \\
\end{array}$ & & & & \\
\hline \multicolumn{7}{|l|}{ Females ages $20-24$} \\
\hline Lagged female gonorrhea rate & & & $\begin{array}{r}0.643 \\
(24.47)\end{array}$ & & $\begin{array}{l}0.455 \\
(2.11)\end{array}$ & \\
\hline Lagged total rate & & & & $\begin{array}{r}0.655 \\
(23.48)\end{array}$ & & $\begin{array}{c}0.589 \\
(2.53)\end{array}$ \\
\hline Log beer tax & $\begin{array}{l}-0.045 \\
(-0.21)\end{array}$ & $\begin{array}{l}-0.132 \\
(-0.44)\end{array}$ & $\begin{array}{l}-0.048 \\
(-0.57)\end{array}$ & $\begin{array}{r}0.055 \\
(0.63)\end{array}$ & $\begin{array}{l}-0.044 \\
(-0.23)\end{array}$ & $\begin{array}{c}0.004 \\
(0.02)\end{array}$ \\
\hline Lag log beer tax & & $\begin{array}{c}0.108 \\
(0.43)\end{array}$ & & & & \\
\hline Percent dry & $\begin{array}{l}-0.031 \\
(-1.39)\end{array}$ & $\begin{array}{l}-0.006 \\
(-0.39)\end{array}$ & $\begin{array}{l}-0.013 \\
(-1.61)\end{array}$ & $\begin{array}{c}-0.01 \\
(-1.21)\end{array}$ & $\begin{array}{c}0.024 \\
(1.26)\end{array}$ & $\begin{array}{c}0.026 \\
(1.29)\end{array}$ \\
\hline Lag percent dry & & $\begin{array}{l}-0.028 \\
(-1.95)\end{array}$ & & & & \\
\hline 0.10 BAC law & $\begin{array}{l}-0.118 \\
(-1.30)\end{array}$ & $\begin{array}{l}-0.108 \\
(-1.15)\end{array}$ & $\begin{array}{l}-0.088 \\
(-1.91)\end{array}$ & $\begin{array}{l}-0.136 \\
(-2.92)\end{array}$ & $\begin{array}{r}0.137 \\
(1.59)\end{array}$ & $\begin{array}{c}0.124 \\
(1.43)\end{array}$ \\
\hline 0.08 BAC law & $\begin{array}{l}-0.224 \\
(-1.62)\end{array}$ & $\begin{array}{l}-0.208 \\
(-1.48)\end{array}$ & $\begin{array}{l}-0.116 \\
(-2.01)\end{array}$ & $\begin{array}{l}-0.188 \\
(-3.19)\end{array}$ & $\begin{array}{c}0.139 \\
(1.25)\end{array}$ & $\begin{array}{c}0.131 \\
(1.26)\end{array}$ \\
\hline Zero tolerance law & $\begin{array}{l}-0.013 \\
(-0.26)\end{array}$ & $\begin{array}{l}-0.010 \\
(-0.20)\end{array}$ & $\begin{array}{l}-0.020 \\
(-0.75)\end{array}$ & $\begin{array}{l}-0.002 \\
(-0.06)\end{array}$ & $\begin{array}{c}0.031 \\
(0.84)\end{array}$ & $\begin{array}{c}0.031 \\
(0.83)\end{array}$ \\
\hline F-test: beer tax, lag beer tax & & $\begin{array}{c}0.11 \\
{[0.894]}\end{array}$ & & & & \\
\hline $\begin{array}{l}\text { F-test: percent dry, lag percent } \\
\text { dry }\end{array}$ & & $\begin{array}{l}1.91 \\
{[0.159]} \\
\end{array}$ & & & & \\
\hline
\end{tabular}


Table 5

AIDS

Males Age 20-29

\begin{tabular}{|c|c|c|c|c|c|c|}
\hline & $\begin{array}{c}\text { OLS } \\
(1)\end{array}$ & $\begin{array}{c}\text { Lagged } \\
\text { OLS } \\
(2) \\
\end{array}$ & $\begin{array}{c}\text { Lagged } \\
\text { Dependent } \\
\text { Variable } \\
\text { OLS } \\
(3) \\
\end{array}$ & $\begin{array}{c}\text { Lagged } \\
\text { Total } \\
\text { Rate } \\
\text { OLS } \\
(4) \\
\end{array}$ & $\begin{array}{c}\text { Lagged } \\
\text { Dependent } \\
\text { Variable } \\
\text { FD2SLS } \\
(5)\end{array}$ & $\begin{array}{c}\text { Lagged } \\
\text { Total } \\
\text { Rate } \\
\text { FD2SLS } \\
(6)\end{array}$ \\
\hline Lagged male AIDS rate & & & $\begin{array}{c}0.185 \\
(4.04)\end{array}$ & & $\begin{array}{c}0.102 \\
(1.53)\end{array}$ & \\
\hline Lagged total rate & & & & $\begin{array}{r}0.224 \\
(4.90)\end{array}$ & & $\begin{array}{r}0.153 \\
(2.11)\end{array}$ \\
\hline Log beer tax & $\begin{array}{l}-0.513 \\
(-2.92)\end{array}$ & $\begin{array}{l}-0.245 \\
(-0.90)\end{array}$ & $\begin{array}{l}-0.434 \\
(-2.74)\end{array}$ & $\begin{array}{c}-0.41 \\
(-2.61)\end{array}$ & $\begin{array}{l}-0.203 \\
(-1.12)\end{array}$ & $\begin{array}{l}-0.204 \\
(-1.11)\end{array}$ \\
\hline First lag log beer tax & & $\begin{array}{c}0.104 \\
(0.40)\end{array}$ & & & & \\
\hline Second lag log beer tax & & $\begin{array}{l}-0.711 \\
(-6.58)\end{array}$ & & & & \\
\hline Percent dry & $\begin{array}{c}0.024 \\
(1.53)\end{array}$ & $\begin{array}{c}0.026 \\
(0.98)\end{array}$ & $\begin{array}{c}0.022 \\
(1.72)\end{array}$ & $\begin{array}{c}0.022 \\
(1.75)\end{array}$ & $\begin{array}{c}0.005 \\
(0.14)\end{array}$ & $\begin{array}{r}0.006 \\
(0.18)\end{array}$ \\
\hline Lag percent dry & & $\begin{array}{l}-0.003 \\
(-0.14)\end{array}$ & & & & \\
\hline 0.10 BAC law & $\begin{array}{r}0.017 \\
(0.24)\end{array}$ & $\begin{array}{l}-0.001 \\
(-0.01)\end{array}$ & $\begin{array}{r}0.019 \\
(0.33)\end{array}$ & $\begin{array}{r}0.023 \\
(0.44)\end{array}$ & $\begin{array}{r}0.127 \\
(1.11)\end{array}$ & $\begin{array}{r}0.133 \\
(1.11)\end{array}$ \\
\hline 0.08 BAC law & $\begin{array}{r}0.021 \\
(0.19)\end{array}$ & $\begin{array}{l}-0.052 \\
(-0.46)\end{array}$ & $\begin{array}{c}0.012 \\
(0.14)\end{array}$ & $\begin{array}{r}0.021 \\
(0.23)\end{array}$ & $\begin{array}{c}0.106 \\
(0.72)\end{array}$ & $\begin{array}{r}0.107 \\
(0.70)\end{array}$ \\
\hline Zero tolerance law & $\begin{array}{c}0.028 \\
(0.47)\end{array}$ & $\begin{array}{r}0.029 \\
(0.49)\end{array}$ & $\begin{array}{c}0.029 \\
(0.58)\end{array}$ & $\begin{array}{r}0.035 \\
(0.72)\end{array}$ & $\begin{array}{c}0.049 \\
(0.86)\end{array}$ & $\begin{array}{r}0.053 \\
(0.93)\end{array}$ \\
\hline Unemployment & $\begin{array}{c}0.082 \\
(3.86)\end{array}$ & $\begin{array}{c}0.075 \\
(3.52)\end{array}$ & $\begin{array}{r}0.068 \\
(3.90)\end{array}$ & $\begin{array}{r}0.066 \\
(3.90)\end{array}$ & $\begin{array}{l}0.055 \\
(2.71)\end{array}$ & $\begin{array}{r}0.054 \\
(2.61)\end{array}$ \\
\hline Real income & $\begin{array}{c}0.01 \\
(2.63)\end{array}$ & $\begin{array}{c}0.008 \\
(2.05)\end{array}$ & $\begin{array}{c}0.009 \\
(2.85)\end{array}$ & $\begin{array}{r}0.009 \\
(2.61)\end{array}$ & $\begin{array}{c}0.005 \\
(0.72)\end{array}$ & $\begin{array}{r}0.004 \\
(0.62)\end{array}$ \\
\hline College degree & $\begin{array}{c}-0.193 \\
(-6.19)\end{array}$ & $\begin{array}{c}-0.186 \\
(-6.29)\end{array}$ & $\begin{array}{c}-0.162 \\
(-5.82)\end{array}$ & $\begin{array}{c}-0.156 \\
(-5.69)\end{array}$ & $\begin{array}{c}-0.077 \\
(-2.28)\end{array}$ & $\begin{array}{r}-0.077 \\
(-2.29)\end{array}$ \\
\hline Percent Mormon & $\begin{array}{c}0.06 \\
(1.69)\end{array}$ & $\begin{array}{c}0.105 \\
(3.06)\end{array}$ & $\begin{array}{c}0.068 \\
(2.12)\end{array}$ & $\begin{array}{r}0.077 \\
(2.46)\end{array}$ & $\begin{array}{c}-0.06 \\
(-0.72)\end{array}$ & $\begin{array}{c}-0.069 \\
(-0.84)\end{array}$ \\
\hline Percent Southern Baptist & $\begin{array}{c}0.035 \\
(0.58)\end{array}$ & $\begin{array}{c}0.019 \\
(0.34)\end{array}$ & $\begin{array}{c}0.03 \\
(0.62)\end{array}$ & $\begin{array}{c}0.024 \\
(0.53)\end{array}$ & $\begin{array}{c}-0.048 \\
(-0.48)\end{array}$ & $\begin{array}{c}-0.046 \\
(-0.46)\end{array}$ \\
\hline Percent Protestant & $\begin{array}{r}0.039 \\
(1.53)\end{array}$ & $\begin{array}{c}0.035 \\
(1.39)\end{array}$ & $\begin{array}{c}0.032 \\
(1.50)\end{array}$ & $\begin{array}{c}0.03 \\
(1.46)\end{array}$ & $\begin{array}{c}0.029 \\
(0.96)\end{array}$ & $\begin{array}{r}0.027 \\
(0.92)\end{array}$ \\
\hline Percent Catholic & $\begin{array}{l}-0.056 \\
(-3.22)\end{array}$ & $\begin{array}{l}-0.057 \\
(-3.38)\end{array}$ & $\begin{array}{l}-0.041 \\
(-3.10)\end{array}$ & $\begin{array}{l}-0.036 \\
(-2.93)\end{array}$ & $\begin{array}{l}-0.059 \\
(-2.00)\end{array}$ & $\begin{array}{r}-0.056 \\
(-1.89)\end{array}$ \\
\hline F-test: beer tax, lag beer tax & & $\begin{array}{l}23.66 \\
{[0.000]}\end{array}$ & & & & \\
\hline $\begin{array}{l}\text { F-test: percent dry, lag percent } \\
\text { dry }\end{array}$ & & $\begin{array}{l}1.15 \\
{[0.322]}\end{array}$ & & & & \\
\hline R-squared & 0.833 & 0.837 & 0.84 & 0.842 & 0.214 & 0.19 \\
\hline
\end{tabular}


Table 6

AIDS

Males Age 30-34

\begin{tabular}{|c|c|c|c|c|c|c|}
\hline & $\begin{array}{c}\text { OLS } \\
(1)\end{array}$ & $\begin{array}{c}\text { Lagged } \\
\text { OLS } \\
(2) \\
\end{array}$ & $\begin{array}{l}\text { Lagged } \\
\text { Dependent } \\
\text { Variable } \\
\text { OLS } \\
(3) \\
\end{array}$ & $\begin{array}{c}\text { Lagged } \\
\text { Total } \\
\text { Rate } \\
\text { OLS } \\
(4) \\
\end{array}$ & $\begin{array}{c}\text { Lagged } \\
\text { Dependent } \\
\text { Variable } \\
\text { FD2SLS } \\
(5) \\
\end{array}$ & $\begin{array}{c}\text { Lagged } \\
\text { Total } \\
\text { Rate } \\
\text { FD2SLS } \\
(6) \\
\end{array}$ \\
\hline Lagged male AIDS rate & & & $\begin{array}{c}0.233 \\
(5.07)\end{array}$ & & $\begin{array}{c}0.264 \\
(4.25)\end{array}$ & \\
\hline Lagged total rate & & & & $\begin{array}{r}0.247 \\
(5.27)\end{array}$ & & $\begin{array}{r}0.276 \\
(4.43)\end{array}$ \\
\hline Log beer tax & $\begin{array}{l}-0.315 \\
(-2.49)\end{array}$ & $\begin{array}{l}-0.054 \\
(-0.30)\end{array}$ & $\begin{array}{l}-0.248 \\
(-2.67)\end{array}$ & $\begin{array}{l}-0.223 \\
(-2.37)\end{array}$ & $\begin{array}{c}0.06 \\
(0.46)\end{array}$ & $\begin{array}{r}0.071 \\
(0.55)\end{array}$ \\
\hline First lag log beer tax & & $\begin{array}{c}0.071 \\
(0.40)\end{array}$ & & & & \\
\hline Second lag log beer tax & & $\begin{array}{l}-0.655 \\
(-6.74)\end{array}$ & & & & \\
\hline Percent dry & $\begin{array}{c}0.019 \\
(0.97)\end{array}$ & $\begin{array}{r}0.019 \\
(0.64)\end{array}$ & $\begin{array}{c}0.016 \\
(1.07)\end{array}$ & $\begin{array}{r}0.017 \\
(1.13)\end{array}$ & $\begin{array}{l}-0.007 \\
(-0.28)\end{array}$ & $\begin{array}{c}-0.003 \\
(-0.10)\end{array}$ \\
\hline Lag percent dry & & $\begin{array}{r}-.00002 \\
(-0.0008)\end{array}$ & & & & \\
\hline 0.10 BAC law & $\begin{array}{c}0.004 \\
(0.05)\end{array}$ & $\begin{array}{c}-0.013 \\
(-0.17)\end{array}$ & $\begin{array}{c}0.005 \\
(0.08)\end{array}$ & $\begin{array}{r}0.011 \\
(0.19)\end{array}$ & $\begin{array}{c}0.084 \\
(0.96)\end{array}$ & $\begin{array}{r}0.088 \\
(0.99)\end{array}$ \\
\hline 0.08 BAC law & $\begin{array}{c}0.034 \\
(0.28)\end{array}$ & $\begin{array}{l}-0.035 \\
(-0.29)\end{array}$ & $\begin{array}{c}0.041 \\
(0.46)\end{array}$ & $\begin{array}{c}0.052 \\
(0.59)\end{array}$ & $\begin{array}{r}0.197 \\
(1.83)\end{array}$ & $\begin{array}{r}0.203 \\
(1.88)\end{array}$ \\
\hline Zero tolerance law & $\begin{array}{c}-0.036 \\
(-0.74)\end{array}$ & $\begin{array}{l}-0.036 \\
(-0.72)\end{array}$ & $\begin{array}{l}-0.037 \\
(-0.97)\end{array}$ & $\begin{array}{l}-0.032 \\
(-0.85)\end{array}$ & $\begin{array}{c}0.005 \\
(0.09)\end{array}$ & $\begin{array}{r}0.003 \\
(0.05)\end{array}$ \\
\hline Unemployment & $\begin{array}{c}0.061 \\
(3.48)\end{array}$ & $\begin{array}{c}0.055 \\
(3.18)\end{array}$ & $\begin{array}{c}0.046 \\
(3.59)\end{array}$ & $\begin{array}{c}0.045 \\
(3.44)\end{array}$ & $\begin{array}{c}0.019 \\
(0.90)\end{array}$ & $\begin{array}{r}0.019 \\
(0.88)\end{array}$ \\
\hline Real income & $\begin{array}{c}0.002 \\
(0.62)\end{array}$ & $\begin{array}{l}-0.0002 \\
(-0.05)\end{array}$ & $\begin{array}{c}0.002 \\
(0.67)\end{array}$ & $\begin{array}{r}0.001 \\
(0.45)\end{array}$ & $\begin{array}{c}-0.003 \\
(-0.48)\end{array}$ & $\begin{array}{c}-0.003 \\
(-0.48)\end{array}$ \\
\hline College degree & $\begin{array}{l}-0.147 \\
(-5.61)\end{array}$ & $\begin{array}{l}-0.139 \\
(-5.53)\end{array}$ & $\begin{array}{l}-0.104 \\
(-4.77)\end{array}$ & $\begin{array}{c}-0.104 \\
(-4.76)\end{array}$ & $\begin{array}{c}0.001 \\
(0.05)\end{array}$ & $\begin{array}{c}-0.001 \\
(-0.07)\end{array}$ \\
\hline Percent Mormon & $\begin{array}{c}0.051 \\
(1.14)\end{array}$ & $\begin{array}{c}0.094 \\
(1.99)\end{array}$ & $\begin{array}{c}0.048 \\
(1.46)\end{array}$ & $\begin{array}{c}0.053 \\
(1.55)\end{array}$ & $\begin{array}{r}0.035 \\
(0.40)\end{array}$ & $\begin{array}{c}0.036 \\
(0.41)\end{array}$ \\
\hline Percent Southern Baptist & $\begin{array}{c}0.084 \\
(1.35)\end{array}$ & $\begin{array}{c}0.068 \\
(1.10)\end{array}$ & $\begin{array}{c}0.054 \\
(1.12)\end{array}$ & $\begin{array}{r}0.057 \\
(1.11)\end{array}$ & $\begin{array}{l}-0.101 \\
(-0.85)\end{array}$ & $\begin{array}{c}-0.103 \\
(-0.86)\end{array}$ \\
\hline Percent Protestant & $\begin{array}{c}0.064 \\
(2.66)\end{array}$ & $\begin{array}{c}0.06 \\
(2.53)\end{array}$ & $\begin{array}{r}0.049 \\
(2.58)\end{array}$ & $\begin{array}{r}0.049 \\
(2.61)\end{array}$ & $\begin{array}{c}0.045 \\
(1.70)\end{array}$ & $\begin{array}{c}0.046 \\
(1.70)\end{array}$ \\
\hline Percent Catholic & $\begin{array}{l}-0.079 \\
(-3.64)\end{array}$ & $\begin{array}{l}-0.079 \\
(-3.72)\end{array}$ & $\begin{array}{l}-0.055 \\
(-3.59)\end{array}$ & $\begin{array}{l}-0.053 \\
(-3.51)\end{array}$ & $\begin{array}{l}-0.047 \\
(-1.76)\end{array}$ & $\begin{array}{l}-0.045 \\
(-1.71)\end{array}$ \\
\hline F-test: beer tax, lag beer tax & & $\begin{array}{l}20.09 \\
{[0.000]}\end{array}$ & & & & \\
\hline $\begin{array}{l}\text { F-test: percent dry, lag percent } \\
\text { dry }\end{array}$ & & $\begin{array}{l}0.45 \\
{[0.641]}\end{array}$ & & & & \\
\hline R-squared & 0.841 & 0.844 & 0.853 & 0.854 & 0.078 & 0.083 \\
\hline
\end{tabular}

Note: t-statistics in parentheses, p-values in brackets, and intercept not shown. Standard errors are clustered by MSA. All independent variables are lagged 8 years. All models include MSA and year dummies and are weighted by the MSA population. $\mathrm{N}=1854$. 
Table 7

AIDS

Females

\begin{tabular}{|c|c|c|c|c|c|c|}
\hline & $\begin{array}{l}\text { OLS } \\
(1)\end{array}$ & $\begin{array}{c}\text { Lagged } \\
\text { OLS } \\
(2)\end{array}$ & $\begin{array}{l}\text { Lagged } \\
\text { Dependent } \\
\text { Variable } \\
\text { OLS } \\
\text { (3) }\end{array}$ & $\begin{array}{c}\text { Lagged } \\
\text { Total } \\
\text { Rate } \\
\text { OLS } \\
(4)\end{array}$ & $\begin{array}{l}\text { Lagged } \\
\text { Dependent } \\
\text { Variable } \\
\text { FD2SLS } \\
\text { (5) }\end{array}$ & $\begin{array}{c}\text { Lagged } \\
\text { Total } \\
\text { Rate } \\
\text { FD2SLS } \\
\text { (6) }\end{array}$ \\
\hline \multicolumn{7}{|l|}{ Females ages $20-29$} \\
\hline Lagged female AIDS rate & & & $\begin{array}{r}0.155 \\
(4.20)\end{array}$ & & $\begin{array}{c}0.15 \\
(2.70)\end{array}$ & \\
\hline Lagged total rate & & & & $\begin{array}{r}0.155 \\
(2.83)\end{array}$ & & $\begin{array}{c}0.012 \\
(0.18)\end{array}$ \\
\hline Log beer tax & $\begin{array}{l}-0.362 \\
(-1.67)\end{array}$ & $\begin{array}{r}0.309 \\
(0.89)\end{array}$ & $\begin{array}{l}-0.31 \\
(-1.61)\end{array}$ & $\begin{array}{l}-0.291 \\
(-1.41)\end{array}$ & $\begin{array}{r}0.044 \\
(0.11)\end{array}$ & $\begin{array}{r}0.038 \\
(0.10)\end{array}$ \\
\hline First lag log beer tax & & $\begin{array}{l}-0.333 \\
(-0.63)\end{array}$ & & & & \\
\hline Second lag log beer tax & & $\begin{array}{l}-0.816 \\
(-4.77)\end{array}$ & & & & \\
\hline Percent dry & $\begin{array}{l}-0.009 \\
(-0.86)\end{array}$ & $\begin{array}{l}-0.033 \\
(-1.72)\end{array}$ & $\begin{array}{l}-0.006 \\
(-0.68)\end{array}$ & $\begin{array}{l}-0.01 \\
(-0.97)\end{array}$ & $\begin{array}{l}-0.003 \\
(-0.10)\end{array}$ & $\begin{array}{l}-0.008 \\
(-0.29)\end{array}$ \\
\hline Lag percent dry & & $\begin{array}{r}0.027 \\
(1.20)\end{array}$ & & & & \\
\hline 0.10 BAC law & $\begin{array}{l}-0.039 \\
(-0.27)\end{array}$ & $\begin{array}{l}-0.067 \\
(-0.46)\end{array}$ & $\begin{array}{l}-0.041 \\
(-0.34)\end{array}$ & $\begin{array}{l}-0.034 \\
(-0.25)\end{array}$ & $\begin{array}{l}-0.033 \\
(-0.21)\end{array}$ & $\begin{array}{l}-0.052 \\
(-0.34)\end{array}$ \\
\hline 0.08 BAC law & $\begin{array}{c}-0.252 \\
(-1.00)\end{array}$ & $\begin{array}{c}-0.38 \\
(-1.51)\end{array}$ & $\begin{array}{r}-0.259 \\
(-1.21)\end{array}$ & $\begin{array}{c}-0.252 \\
(-1.07)\end{array}$ & $\begin{array}{c}-0.157 \\
(-0.59)\end{array}$ & $\begin{array}{c}-0.167 \\
(-0.65)\end{array}$ \\
\hline Zero tolerance law & $\begin{array}{c}-0.071 \\
(-0.73)\end{array}$ & $\begin{array}{l}-0.082 \\
(-0.85)\end{array}$ & $\begin{array}{l}-0.06 \\
(-0.73)\end{array}$ & $\begin{array}{l}-0.066 \\
(-0.71)\end{array}$ & $\begin{array}{c}0.096 \\
(0.70)\end{array}$ & $\begin{array}{c}0.083 \\
(0.68)\end{array}$ \\
\hline F-test: beer tax, lag beer tax & & $\begin{array}{c}7.96 \\
{[0.000]}\end{array}$ & & & & \\
\hline $\begin{array}{l}\text { F-test: percent dry, lag percent } \\
\text { dry }\end{array}$ & & $\begin{array}{c}1.66 \\
{[0.195]}\end{array}$ & & & & \\
\hline \multicolumn{7}{|l|}{ Females ages $30-34$} \\
\hline Lagged female AIDS rate & & & $\begin{array}{c}0.086 \\
(2.43)\end{array}$ & & $\begin{array}{r}0.019 \\
(0.36)\end{array}$ & \\
\hline Lagged total rate & & & & $\begin{array}{r}0.163 \\
(3.30)\end{array}$ & & $\begin{array}{l}-0.037 \\
(-0.56)\end{array}$ \\
\hline Log beer tax & $\begin{array}{l}-0.946 \\
(-3.66)\end{array}$ & $\begin{array}{r}0.509 \\
(1.01)\end{array}$ & $\begin{array}{l}-0.863 \\
(-3.52)\end{array}$ & $\begin{array}{l}-0.886 \\
(-3.66)\end{array}$ & $\begin{array}{r}0.859 \\
(1.37)\end{array}$ & $\begin{array}{c}0.846 \\
(1.36)\end{array}$ \\
\hline First lag log beer tax & & $\begin{array}{l}-1.401 \\
(-2.26)\end{array}$ & & & & \\
\hline Second lag log beer tax & & $\begin{array}{c}-0.657 \\
(-3.35)\end{array}$ & & & & \\
\hline Percent dry & $\begin{array}{c}-0.071 \\
(-2.96)\end{array}$ & $\begin{array}{l}-0.047 \\
(-1.43)\end{array}$ & $\begin{array}{c}-0.064 \\
(-2.79)\end{array}$ & $\begin{array}{c}-0.072 \\
(-3.08)\end{array}$ & $\begin{array}{c}-0.004 \\
(-0.09)\end{array}$ & $\begin{array}{c}-0.005 \\
(-0.11)\end{array}$ \\
\hline Lag percent dry & & $\begin{array}{l}-0.025 \\
(-0.78)\end{array}$ & & & & \\
\hline 0.10 BAC law & $\begin{array}{l}-0.073 \\
(-0.45)\end{array}$ & $\begin{array}{l}-0.106 \\
(-0.66)\end{array}$ & $\begin{array}{c}-0.062 \\
(-0.41)\end{array}$ & $\begin{array}{l}-0.068 \\
(-0.45)\end{array}$ & $\begin{array}{c}0.243 \\
(1.32)\end{array}$ & $\begin{array}{c}0.235 \\
(1.25)\end{array}$ \\
\hline
\end{tabular}




\begin{tabular}{lccrrrr}
0.08 BAC law & -0.114 & -0.257 & -0.111 & -0.102 & 0.102 & 0.095 \\
& $(-0.45)$ & $(-1.00)$ & $(-0.47)$ & $(-0.42)$ & $(0.37)$ & $(0.35)$ \\
Zero tolerance law & 0.015 & 0.013 & 0.019 & 0.018 & 0.125 & 0.125 \\
& $(0.11)$ & $(0.09)$ & $(0.15)$ & $(0.14)$ & $(0.75)$ & $(0.76)$ \\
F-test: beer tax, lag beer tax & & 17.15 & & & & \\
& {$[0.000]$} & & & \\
F-test: percent dry, lag percent & & 4.26 & & \\
dry & \multicolumn{3}{c}{$[0.017]$} \\
\hline
\end{tabular}

Note: t-statistics in parentheses, p-values in brackets, and intercept not shown. Standard errors are clustered by MSA. All independent variables are lagged 8 years. All models include state characteristics (unemployment income, education, religion), MSA and year dummies, and are weighted by the MSA population for the age group. $\mathrm{N}=1854$. 